\title{
The Influential Factors of Successful Public Parks in Malaysia
}

\author{
Siti Rasidah Md Sakip, Norizan Mt Akhir, Siti Syamimi Omar \\ Department of Landscape Architecture, \\ Universiti Teknologi MARA, 32610 Seri Iskandar Perak, Malaysia \\ Sitir704@perak.uitm.edu.my, noriz102@perak.uitm.edu.my, sitisyamimi@perak.uitm.edu.my
}

\begin{abstract}
The main factors that contribute in successful of the park are good of access and linkage (GAL), degree of comfort and image (DCl), user and activities (UAC) and sociability (SOC). Six public park in Malaysia involved in this study conducted through a survey using a questionnaire. The validation and reliability of four constructs were done using Cronbach's Alpha. The result found that all construct achieved Cronbach's Alpha coefficient level exceeding 0.60 ( $G A L=0.89, D C l=0.82, U A C=0.82, S O C=0.82$ ). These results explain all items in GAL, DCl, UAC and SOC construct have good internal consistency, indicating that all dimensions have a good reliability value.
\end{abstract}

Keywords: public park, perception, accessibility, lingkages

eISSN 2398-4295 @ 2018. The Authors. Published for AMER ABRA cE-Bs by e-International Publishing House, Ltd., UK. This is an open-access article under the CC BY-NC-ND license (http://creativecommons.org/licenses/bync-nd/4.0/). Peer-review under responsibility of AMER (Association of Malaysian Environment-Behaviour Researchers), ABRA (Association of Behavioural Researchers on Asians) and cE-Bs (Centre for EnvironmentBehaviour Studies), Faculty of Architecture, Planning \& Surveying, Universiti Teknologi MARA, Malaysia.

DOI: http://dx.doi.org/10.21834/ajbes.v3i12.135 


\subsection{Introduction}

Park is an important space in the relationship of man and nature to promote and provide space for physical activity, health behavior, and can reduce some diseases such as diabetes and certain cancer. Public parks have always been an important component in an urban area. The public park in Malaysia seems to be developed for recreation and relaxation for city or town community. The category of public parks based on Malaysia Town and Country Planning Department (TCPD) Planning Guideline for Open Space and Recreation (2000); they are national park, regional park, town park, local park, neighbourhood park, children playground and play lot area. Consequently, the six public parks, namely Taman Botani Negara Shah Alam (TBNSA)- national park, Taman Metropolitan Kepong (TMK)- a regional park, Taman Tasik Titiwangsa (TTT)- local park, Taman KLCC (TK)- urban park, Taman Tasik Shah Alam (TTSA)- neighbourhood park and Taman Tasik Perdana (TTP)- regional park will be studied the factors that contributed to the successful public park (refer to Figure 1). Hence, the main objective of this paper is to examine the main factors that contribute for successful public park in Malaysia.

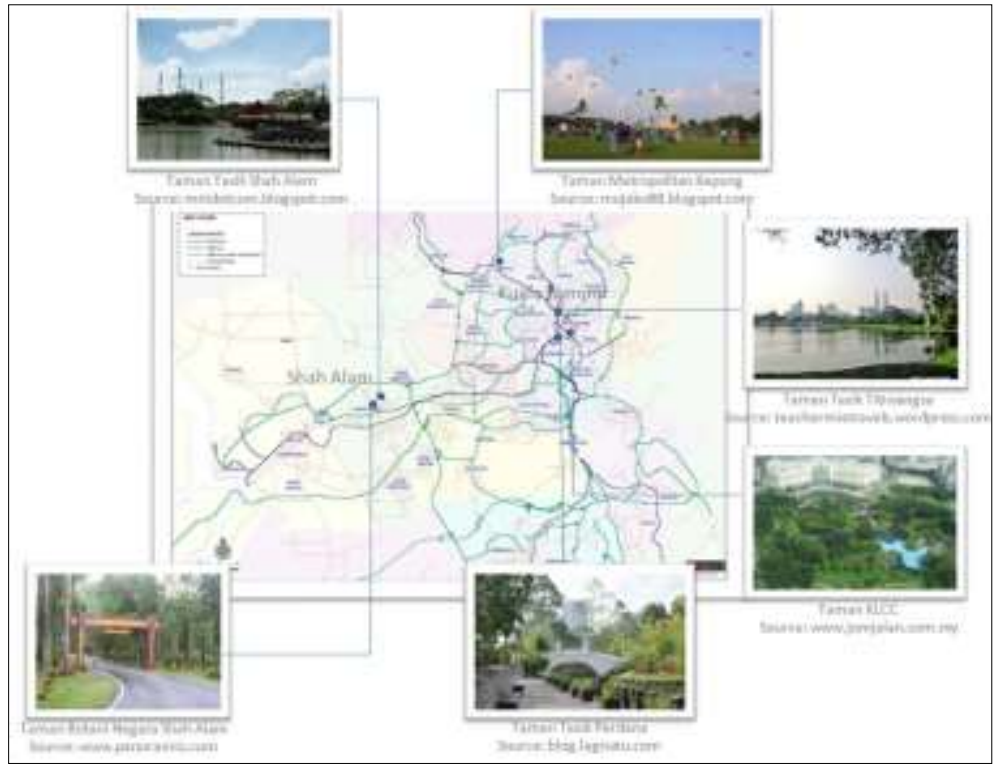

Figure 1: Map of six public parks in Klang Valley.

Source: Regroup Associates

\subsection{Literature Review}

Public space is considered as a place for social encounter and interactions which reflect the problems and challenges of its users (Mennat-Allah El-Husseiny \& Karim Kesseiba, 2012). Parks and green spaces should not only provide places to recreate, but create an opportunity 
for psychological revitalization of daily life (Rabiatul Adawiyah Nasir et al, 2013) and affect the value of houses (Farahwaheda, S, Noriah, O, \& Abdul, H.N (2010). In Malaysia, types of open space based on (TCPD) Planning Guideline for Open Space and Recreation (2000) (Table 1). In this study two types of open space in TCPD are not be measured namely play lot and children playground because of the size of those two parks are less than 1.0 hectares. Parks not only for recreation, it a place for physical activity (Kaczynski \& Henderson, 2008), health behavior such as protects against cardiovascular disease, type 2 diabetes, and certain cancers (Kaczynski \& Henderson, 2008) and enhance the social cohesion (Tabassum, S. \& Sharmin, F., 2013),

The quality of park has relation with planning and design criteria (Nurhayati Abdul Malek et al., 2012), elements of nature such as vegetations, birds and insects as a push factor for visitors' satisfaction in urban recreational areas (Noralizawati, M. \& Noriah, O. 2010). The circulation system in the park is a forms of framework that links all the activity and support areas together (Abu Bakar, J., 2002; Lynch, 1975).

Table 1. Types of Open Space According to TCPD of Malaysia

\begin{tabular}{ll}
\hline Type of Open Space & Minimum Required Area \\
\hline Play lot & 0.2 hectares \\
Children Playground & 0.6 hectares \\
Neighbourhood Park & 2 hectares \\
Local Park & 8 hectares \\
Town Park & 40 hectares \\
Regional Park & 100 hectares \\
National Park & No limit \\
\hline
\end{tabular}

Source: National Landscape Guidelines 2008 \& Planning Guidelines, TCPD

The successful circulation system is the establishment of a clear hierarchy of road (Abu Bakar, J., 2002) that create a functional coherence between the inside of the park and the immediate surroundings (Diyanah, I.A \& Hafazah, A.K, 2012). Within developing countries, there has been very little research regarding the use and perception of green space (Willemse, 2010). Generally, perceptions are very complex and have different views related to age, races, religions, gender, and experiences. In terms of visitors, teenagers and adults have a different interest and activities in a park (Makinen, K \& Tyrvainen, L (2008) cited in Bell et al. (2003). The teenagers often like to explore the environment and to find a territory of their own and they may avoid the adults spaces where the teenagers may feel themselves controlled, criticized or excluded (Lieberg, 1995, Massey, 1998, Bell et al. 2003) as cited by Makinen, K and Tyrvainen, L (2008).

\subsection{Methodology}

This study was done in six public parks in Malaysia, which are Taman Botani Negara Shah Alam (TBNSA), Taman Metropolitan Kepong (TMK), Taman Tasik Titiwangsa (TTT), Taman KLCC (TK), Taman Tasik Shah Alam (TTSA) and Taman Tasik Perdana (TTP). The 
respondents that involved in this study are second year students of Diploma in Landscape Architecture from Higher Education Institution (IPTA) in Malaysia. The respondent have been exposing with the knowledge about factors that create successful park and open space and the relationship between park design and human behavior.

This study is quantitative in nature using a questionnaire. The survey involved asking residents to answer a questionnaire that was administered using face to face interviews. Before to answering the questionnaire, the respondent going to visit six sites at TBNSA, TMK, TTT, TK, TTSA and TTP park. A TBNSA park is the first park that is visited by respondent and followed by TMK, TTT, TK, TTSA and TTP park. The purpose of the site visit is respondent can make their own observation, exploration and that enable them to understand the linkages, activities, images and sociability in a park. The time taken for each park is approximately 1 hour and 30 minutes. This period is considered adequate and sufficient for understanding the environment of the park. After completing the visit to each of the park, the respondents need to answer the questionnaire. In the questionnaire, it contained five parts: Part 1- background information, Part 2- the construct of good accessibility and linkages (GAL), Part 3- the construct of degree of comfort and image (DCl), Part 4 - the construct of user and activities and Part 5- the construct of sociability (SOC). The measurement of constructs or main variable was rated using a Likert scale ranging from 1 to 6 ranging from "Highly Disagree" to "Highly Agree." The high score will indicate that the conduct is good and vice versa if the score obtained is low. The reason for using a 6-point Likert scale without a neutral answer was to induce the respondent to take a stance. Furthermore, the technique of providing the scales "Highly Disagree" to "Highly Agree" will give the result intensity from respondents, thus impacting the distribution of the respondents' score.

\subsection{Results And Discussions}

The validation on the construct is important to verify the items of each construct are valid to measure the dimension using the exploratory factor analysis. According to Nunnally (1978) the ratio of subjects to items recommends a 10 to 1 ratio in EFA. In this research at least 50 samples required to answer for each variable. The sample size of this research is consider adequate since the 60 respondents was participated. The Cronbach's Alpha value was used to determine the level of reliability through the internal consistency for each factor. An itemto-scale value of 0.3 and above was used as the minimum value for a unidimensional scale (de Vaus, 1986), while the scale was considered reliable if the alpha value was 0.6 and above, based on the De Vellis (1991) criteria.

The results of the analysis demonstrated the good accessibility and linkages (GAL) dimensions achieved Alpha value level exceeding $0.60(\mathrm{VC}=0.83, \mathrm{PS}=0.90$ and $\mathrm{PTS}=0.87$ ). For the construct of comfort and image (DCl) there are three dimensions namely placing of sitting area (PSA), Maintenance (MAl) and safety of park (SOP). However, the dimension of PSA and MAI was merged to accumulate the Alpha value level exceeding 0.60 . Therefore, the name of new dimension is sitting and maintenance (SMA) with the numbers of item is 9 . From the 9 items listed and used, two items were omitted as they recorded a corrected itemto-total correlation value of below 0.3 , while the total alpha value of the 9 items $=0.62$. Those 
two items were; (i) "most of benches placing in shaded are" and (ii) "easy to get the sitting area". After these two items were eliminated and analysis was redone, the resulting Alpha value $=0.72$. Meanwhile the dimension of safety of park (SOP) included 11 items and the alpha value $=0.81$ with the item-to-total correlation value 3.0 and above. The result shows that all items in SOP are valid to measure the SOP.

The construct of user and activities (UAC), it's employed four dimensions namely - users (USE), social activities (SAC), physical activities (PHY) and special attraction (SAT). However, the dimension of USE and SAC was combined similar as a dimension of SMA that was mentioned before. So, the name of this dimension is user and social activities (USA) with 12 items. It is also similar happen with PHY and SAT dimension to merge to be a new dimension with name activities and special attraction (ASA) with 14 items. From the 12 items listed and used in USA dimension, two items were omitted as they recorded a corrected itemto-total correlation value of below 0.3 , while the total alpha value of the 9 items $=0.62$. Those two items were; (i) "user- community" and (ii) "space for meeting a friend". After these two items were eliminated and analysis was redone, the result of Alpha value $=0.72$. It is similar with ASA dimension, there are two items were eliminated as they recorded a corrected itemto-total correlation value of below 0.3 . Those two items were; (i) "jogging area are provided" and (ii) "place for playing roller blade is provided". After these two items were eliminated and analysis was redone, the Alpha value $=0.76$.

For the measurement of sociability (SOC) there are two main dimensions, namely; opportunity to socialize (OPS) and environment (ENV). There are 3 items contribute in OPS dimension and the total alpha value is 0.91 with corrected item-to-total correlation more than 0.3. Meanwhile in ENV dimension, employed 7 items and cronbach's alpha value is 0.70 with corrected item-to-total correlation 0.3 and above (refer Table 2).

Table 2. Results of the reliability of good accessibility and linkages, comfort and images, user and activities, and socialibility dimensions

\begin{tabular}{|c|c|c|c|c|c|}
\hline Constructs & Dimension & Items & Description of Items & $\begin{array}{l}\text { Corrected } \\
\text { Item-Total } \\
\text { Correlation }\end{array}$ & Reliability \\
\hline $\begin{array}{l}\text { Good } \\
\text { accessibility } \\
\text { and linkages } \\
\text { (GAL) }\end{array}$ & $\begin{array}{l}\text { Vehicular } \\
\text { circulation } \\
\text { (VC) }\end{array}$ & $\begin{array}{l}1 \\
2 \\
3 \\
4 \\
5\end{array}$ & $\begin{array}{l}\text { The condition are good } \\
\text { Entrance statement very clear } \\
\text { Route- clear from entrance to exit } \\
\text { Parking space visible outer route } \\
\text { The size of parking space are good }\end{array}$ & $\begin{array}{l}0.619 \\
0.703 \\
0.692 \\
0.672 \\
0.512\end{array}$ & 0.836 \\
\hline & $\begin{array}{l}\text { pedestrian } \\
\text { system (PS) }\end{array}$ & $\begin{array}{l}1 \\
2 \\
3 \\
4 \\
5 \\
6\end{array}$ & $\begin{array}{l}\text { Pedestrian entrance are good } \\
\text { Road crossing are good } \\
\text { Connected to main route are good } \\
\text { Size of walkway are good } \\
\text { Condition of walkway are good } \\
\text { Signage to facilities are clear explained }\end{array}$ & $\begin{array}{l}0.810 \\
0.773 \\
0.762 \\
0.624 \\
0.751 \\
0.692\end{array}$ & 0.902 \\
\hline & $\begin{array}{l}\text { public } \\
\text { transport } \\
\text { system (PTS) }\end{array}$ & $\begin{array}{l}1 \\
2\end{array}$ & $\begin{array}{l}\text { Proximity to bus stop } \\
\text { The public transport within transit route }\end{array}$ & $\begin{array}{l}0.785 \\
0.785\end{array}$ & 0.879 \\
\hline
\end{tabular}


Md Sakip, S.R., et.al. / Asian Journal of Behavioural Studies (AjBeS), 3(12) Jul / Aug 2018 (p. 195-205)

\begin{tabular}{|c|c|c|c|c|c|}
\hline \multirow[t]{2}{*}{$\begin{array}{l}\text { Comfort and } \\
\text { Image (DCl) }\end{array}$} & $\begin{array}{l}\text { Sitting and } \\
\text { maintenance } \\
\text { (SMA) }\end{array}$ & $\begin{array}{l}1 \\
2 \\
3 \\
4 \\
5 \\
6 \\
7 \\
8\end{array}$ & $\begin{array}{l}\text { Most of benches placing in shaded area } \\
\text { placing in area with high activities } \\
\text { Easy to get the sitting area } \\
50 \% \text { benches or sitting area under shelter } \\
50 \% \text { benches or sitting area in open area } \\
\text { The area shows a good maintenance } \\
\text { All facilities that provided in a good } \\
\text { conditions } \\
50 \% \text { of facilities in a good condition } \\
50 \% \text { of facilities in a bad condition }\end{array}$ & $\begin{array}{l}- \\
0.601 \\
0.549 \\
0.513 \\
0.361 \\
0.631 \\
0.595 \\
0.381\end{array}$ & 0.72 \\
\hline & $\begin{array}{l}\text { Safety of park } \\
\text { (SOP) }\end{array}$ & $\begin{array}{l}1 \\
2 \\
3 \\
4 \\
5 \\
6 \\
7 \\
8 \\
8 \\
9 \\
10 \\
11\end{array}$ & $\begin{array}{l}\text { Near the road } \\
\text { Near to residential area } \\
\text { Near to commercial area } \\
\text { Near to natural area } \\
\text { Presence of security such as police, } \\
\text { security park } \\
\text { Safety of signboard such as community } \\
\text { surveillance } \\
\text { The existence of CCTV } \\
\text { Vehicles are allowed into the park } \\
\text { Bicycles are allowed into the park } \\
\text { Motorcycles are allowed into the park } \\
\text { Car are allowed into the park }\end{array}$ & $\begin{array}{l}0.367 \\
0.463 \\
0.349 \\
0.385 \\
0.458 \\
0.521 \\
0.428 \\
0.628 \\
0.520 \\
0.569 \\
0.540 \\
\end{array}$ & 0.81 \\
\hline \multirow[t]{2}{*}{$\begin{array}{l}\text { User and } \\
\text { Activities } \\
\text { (UAC) }\end{array}$} & $\begin{array}{l}\text { User and } \\
\text { social } \\
\text { activities } \\
\text { (USA) }\end{array}$ & $\begin{array}{l}1 \\
2 \\
3 \\
4 \\
4 \\
5 \\
6 \\
7 \\
8 \\
9 \\
10 \\
11 \\
12 \\
\end{array}$ & $\begin{array}{l}\text { Family } \\
\text { Teenagers } \\
\text { Less abled/ disabled people (Handicaped/ } \\
\text { senior citizen/ pregnancy woman) } \\
\text { Toddlers } \\
\text { Community } \\
\text { Space for fly a kite } \\
\text { Space for boating } \\
\text { Space for picnic } \\
\text { Space for meeting friend } \\
\text { Space for eating } \\
\text { Scenic view for capture the photo } \\
\text { Playing at playground }\end{array}$ & $\begin{array}{c}0.514 \\
0.495 \\
0.331 \\
\\
0.60 \\
- \\
0.278 \\
0.301 \\
0.523 \\
- \\
0.486 \\
0.521 \\
0.501 \\
\end{array}$ & 0.72 \\
\hline & $\begin{array}{l}\text { Activities and } \\
\text { special } \\
\text { attraction } \\
\text { (ASA) }\end{array}$ & $\begin{array}{l}1 \\
2 \\
3 \\
4 \\
5 \\
6 \\
7 \\
8 \\
9 \\
10 \\
11 \\
12 \\
13 \\
14\end{array}$ & $\begin{array}{l}\text { Jogging area are provided } \\
\text { Walking area are good } \\
\text { Place for playing roller blade is provided } \\
\text { Skating area is provided } \\
\text { Cycling area is provided } \\
\text { Relaxing area is provided } \\
\text { Area purposely for reading are provided } \\
\text { Water fountain is very attractive } \\
\text { Playground is very attractive } \\
\text { Statues/ sculpture are very attractive } \\
\text { Park layout design is very attractive } \\
\text { Hardscape elements are very attractive } \\
\text { Softscape in planting design are very } \\
\text { attractive } \\
\text { Plant material selection is very attractive }\end{array}$ & $\begin{array}{c}- \\
0.403 \\
- \\
0.376 \\
0.416 \\
0.349 \\
0.642 \\
0.432 \\
0.453 \\
0.529 \\
0.597 \\
0.603 \\
0.552 \\
0.514\end{array}$ & 0.76 \\
\hline $\begin{array}{l}\text { Sociablity } \\
\text { (SOC) }\end{array}$ & $\begin{array}{l}\text { Opportunity to } \\
\text { socialize } \\
\text { (OPS) }\end{array}$ & $\begin{array}{l}1 \\
2 \\
3\end{array}$ & $\begin{array}{l}\text { Attractive design of park layout make user } \\
\text { attracted to socialize } \\
\text { Facilities that provided enhance the social } \\
\text { activities } \\
\text { Signage explanation is vary clear make us } \\
\text { attracted to socialize }\end{array}$ & $\begin{array}{l}0.832 \\
0.877 \\
0.781\end{array}$ & 0.91 \\
\hline
\end{tabular}




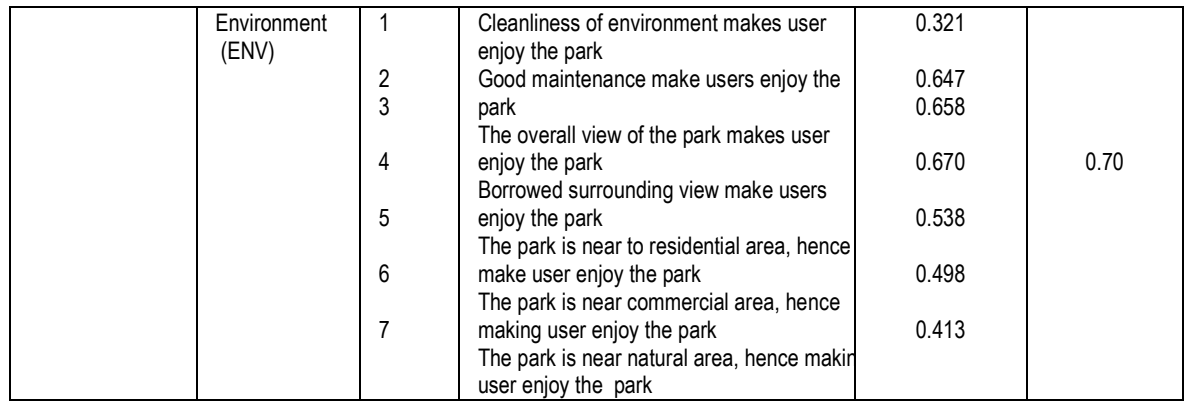

\subsection{Conclusions}

This study investigated the relationship between four main variables; good accessibility \& linkages (GAL), degree of comfort \& image (DCI), users \& activities (UAC) \& sociability $(\mathrm{SOC})$. The relationship between four variables was investigated using Pearson productmoment correlation coefficient. Preliminary analysis was performed to ensure no violation of the assumption or normality, linearity and homoscedasticity. The result shows those variables have strong, positive correlation between GAL with SOC ( $r=.63, p=.00)$, GAL with $\mathrm{DCl}(r=$ $.69, p=.00)$, DCl with SOC $(r=.67, p=.00)$, GAL with UAC $(r=.58, p=.00)$, SOC with UAC $(r=.66, p=.00)$, and DCI with UAC $(r=.62, p=.00)$. These findings show that when the good access and linkage is high there is also the demand of sociability, the degree of comfort and image, user and activities also increase. This output is shown in Table 3.

Table 3. Pearson product-moment correlation between measures of good accessibility and linkages, sociability, degree of comfort and image, and users activities

\begin{tabular}{|c|c|c|c|}
\hline Measures & 1 & 2 & 3 \\
\hline GAL & & & \\
\hline (2) SOC & $.63^{* *}$ & & \\
\hline (3) $\mathrm{DCl}$ & $.69^{* *}$ & $.66^{*+}$ & \\
\hline (4) UAC & $.58^{* *}$ & $.66^{* *}$ & $.62^{* *}$ \\
\hline
\end{tabular}

Results of t-test analysis on gender with a construct found that a sociability (SOC) $(t(330)=-3.66 ; p=0.00)$, degree comfort and image $(D C l)(t(326)=-3.03 ; p=0.00)$ and users and activities (UAC) are significant with gender $(t(328)=-2.31 ; p=0.02)$. However, the result found that gender is not significant with good accessibility and linkages $(G A L)(t(329)=-1.50$; $p=0.13$ ) as shown in Table 4.

In reference to Figure 1, the female gender is higher to all variables of sociability (SOC), degree comfort and image (DCl) and users \& activities (UAC) compare to male gender. These findings refer to mean score of SOC (Female; $M=44.9$, Male=41.1), DCl (Female; $M=73.9$, Male=69.5) and UAC (Female; $M=45.8$, Male=43.7) with gender. This finding indicates that female respondents are more concern on those three main variables or 
construct compare to male respondents. These results may be associated with a woman's ability to ensure security affairs and facilities for mobile

Table 4. T-test analysis on gender with variable of good accessibility and linkages, sociability, degree comfort and image and users and activities

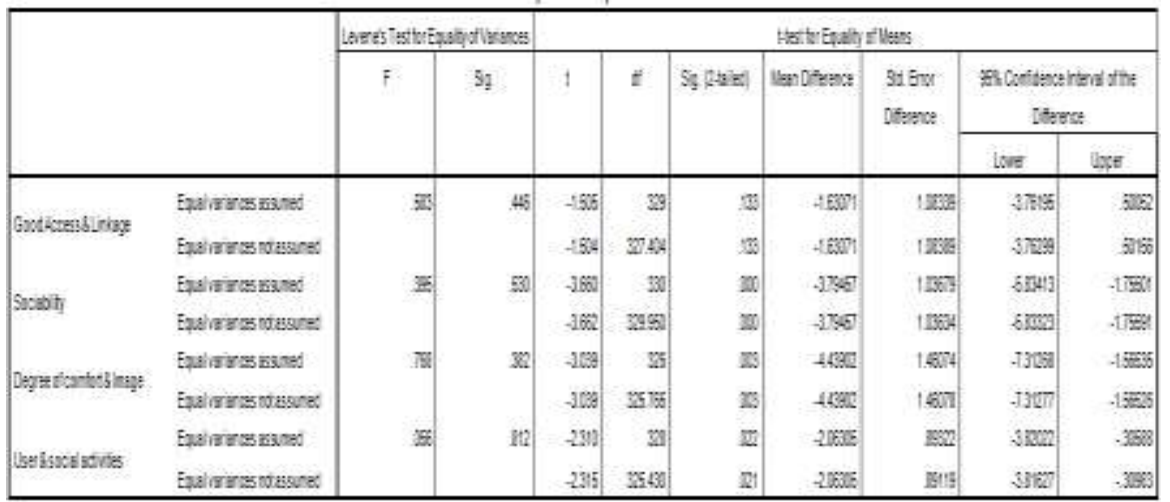

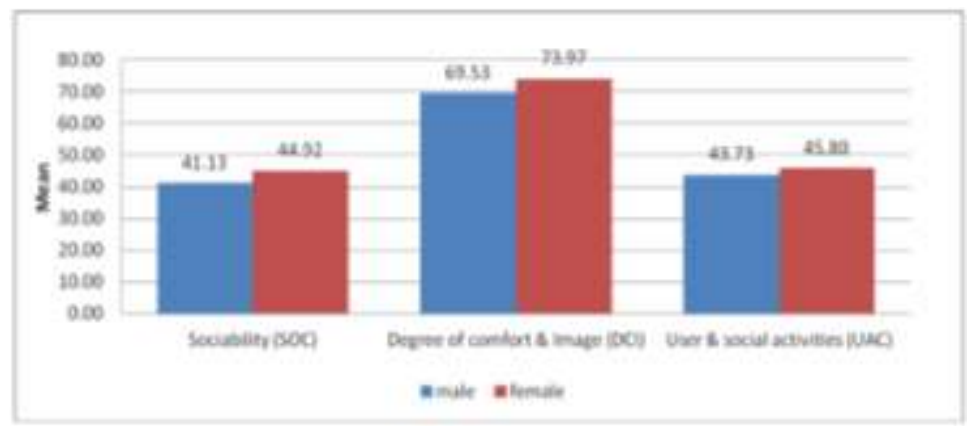

Fig. 1. Comparison between genders with sociability, degree of comfort and image and users and activities

Public parks with proper accessibility and well connected with its surrounding area can improve the value of park environment and can enhance community development and social bondage. This research found that when the good access and linkage, there is also the demand on sociability, the degree of comfort and image and the increasing user and activities. From the analysis, pedestrian system is the most significant factor in determining GAL. Overall mean GAL for all surveyed public parks is high and the most significant GAL dimension is PS as mentioned by Lynch (1960) that the paths as predominant elements in the image of site. In addition the GAL factor contributes to make user attracted to socialize in public park. It means, with good design layout, clear signage for direction and good facilities provided will enhance the social activities. Even user and activities (UAC) factor also 
related to be increased in public park. When more users come to the park, they will create more activities and opportunity to create new identity or image of public park. The next factor is degree of comfort and image ( $\mathrm{DCl})$ which also contribute to success park. Usually users will feel comfortable when they feel the place is safe. For this case, the safety factor result is higher than the maintenance or condition of site facilities. Users are more comfort when the park has clear GAL and next to their place. However the condition of site facilities also be counted in DCl to improve the image of park and useful for user.

In conclusion, to achieve successful public park, GAL should be the main factor in designing a park follow by SOC, UAC and $\mathrm{DCl}$ factors. Besides that, the image of public parks in Malaysia also can be improved and the situation of becoming an abandoned park can be avoided. As a conclusion, all four factors are important in determining the successful of a public park. For future research, it is recommended that different categories of public parks users (according to age, economic background) should be studied in order to get a holistic view of successful public parks design and to cater for larger demographics in future planning of public parks in Malaysia.

\section{Acknowledgement}

The authors would like to thank Universiti Teknologi MARA (UiTM) for providing financial support for this study

\section{References}

Abu Bakar, J. (2002). A Design Guide for Public Parks in Malaysia. Universiti Teknologi Malaysia, Skudai, Johor.

Bernie Dahl and Donald J. Molnar (2003), Anatomy of a Park : Essentials for Recreation Area Planning and Designing, 3rd edition, Waveland Press Inc.

Boone, C.G., Buckley, G.L., Grove, J.M. \& Sister, C. (2009), Parks and People: An environmental justice inquiry in Baltimore, Maryland. Annals of the Association of American Geographers, 99(4), 767-787 as cited by H.E. Wright Wendel et al. (2012), Accessibility and usability: Green space preferences, perceptions, and barriers in a rapidly urbanizing city in Latin America, Landscape and Urban Planning,107, 272- 282

Cohen, D. A., McKenzie, T. L., Sehgal, A., Williamson, S., Golinelli, D., \& Lurie, N.(2007). Contribution of public parks to physical activity. American Journal of Public Health, 97, 509-514.

Dempsey, N. (2008). Does quality of the built environment affect social cohesion?, Proceedings of the Institution of Civil Engineers Urban Design and Planning, 161, 105114.

De Vaus, D. A. (1986) Surveys in Social Research, London, Academic Divison of Unwin Hyman Ltd.

Devellis, R. F. (1991) Scale Development: Theory and Application., Thousand Oaks, CA, Sage.

Diyanah Inani Azmi \& Hafazah Abdul Karim (2012), Implications of Walkability towards Promoting Sustainable Urban Neighbourhood, Procedia - Social and Behavioral Sciences, 50, 204 - 213 
Farahwaheeda, S., Noriah, O. \& Abdul, H.N (2010). The Values of Parks to the House Residents. Asian Journal of Environment-Behaviour Studies, 1(2), 85-94.

Giles-Corti, B., Broomhall, M.H., Knuiman, M., Collins, C., Douglas, K., Ng., K., et al. (2005), increasing walking How important is distance to attractiveness and size of public open space? American Journal of preventive Medicine, 28(2). 169-176 as cited by H.E. Wright Wendel et al. (2012), Accessibility and usability: Green space preferences, perceptions, and barriers in a rapidly urbanizing city in Latin America, Landscape and Urban Planning, 107, 272282

Kaczynski, A. T., \& Henderson, K. A. (2008). Parks and recreation settings and active living: A review of associations with physical activity function and intensity. Journal of Physical Activity \& Health, 5, 619-632.

Lynch, K. (1960). The Image of the City. MIT Press, Cambridge, London.

Makinen, K \& Tyrvainen, L (2008). Teenage Experiences of Public Green Spaces in Suburban Helsinki. Urban Forestry and Urban Greening, 7, 277-289.

Mennat-Allah El-Husseiny \& Karim Kesseiba, (2012), Challenges of Social Sustainability in Neo-liberal Cairo: Requestioning the role of public space, Procedia - Social and Behavioral Sciences, 68, 790 - 803

Mayo, G. (2010). 'Nature in the City': young people's perceptions, values and experiences. Diffusion, Volume 5, Issue 1, The UCLan Journal of Undergraduate Research, University of Central Lancashire.

Norlizawati, M \& Noriah, O. (2010). Push and Pull Factors: Determining the Visitors' Satisfaction at Urban Recreational Areas. Asian Journal of Environment-Behaviour Studies, 1 (2), 77-84

Nunnally, J. C., \& Bernstein, I. H. (1994). Psychometric Theory. New York: McGraw-Hill.

Nurhayati Abdul Malek, \& Manohar Mariapanb (2009), Developing Quality Neighbourhood Parks Criteria, Proceedings of the Urban Forestry Conference 2009 : Lessons for Sustainable Development.: Kuching, Sarawak, Malaysia, 17-19 Nov 2009, p. 94-103 as cited by Nurhayati Abdul Malek, Manohar Mariapanb, Mustafa Kamal Mohd Shariff (2012), The Making of a Quality Neighbourhood Park: A Path Model Approach, Procedia - Social and Behavioral Sciences, 49, $202-214$

Nurhayati Abdul Malek, Manohar Mariapanb, \& Mustafa Kamal Mohd Shariff (2012), The Making of a Quality Neighbourhood Park: A Path Model Approach, Procedia - Social and Behavioral Sciences, 49, 202 - 214

Landcom (2008), Open Space Design Guidelines for Landcom Projects.http://www.landcom.com.au/downloads/uploaded/2008_Open_Spaces_Design_Guidelines_4a54_e43f.pd f downloaded in February 2014.

Parks \& Recreation in Underserved Areas: A Public Health Perspective, National Recreation and Park Association (NRPA), www.nrpa.org/uploadedFiles/nrpa.org/Publications_and_Research/Research/Papers/Parks-Rec Underserved-Areas.pdf downloaded in February 2014.

Pallant, J. (2005). SPSS Survival Manual: A Step By Step Guide To Data Analysis Using SPSS For Windows (Version 12). Allen \& Unwin. Australia

Tabassum, S. \& Sharmin, F. (2013). Accessibility Analysis of Parks at Urban Neighborhood: The Case of Dhaka. Asian Journal of Applied Science and Engineering, 2(2), 48-61.

Project for Public Spaces (PPS). U.S.A. What Makes A Successful Place?www.pps.org downloaded in February 2014.

Project For Public Spaces, http://www.pps.org/reference/what_is_placemaking/, accessed on December 2012 
Rabiatul Adawiyah Nasir, Sabarinah Sh Ahmada, \& Azni Zain Ahmed (2013), Physical Activity and Human Comfort Correlation in an Urban Park in Hot and Humid Conditions, Procedia - Social and Behavioral Sciences, 105, 598 609

Rijal Saffuana, Junaidah Ariffina \& Zamreen Amin. (2012), Planning Park for Liveable Cities: Green Technology Design Practice for Tasik Biru Kundang, Kuang, Selangor, Malaysia, Procedia - Social and Behavioral Sciences, $35,705-712$

State of Queensland, acting through the Department of Innovation and Information Economy, Sport and Recreation Queensland. Australia. Get Active Queensland, Open Space for Sport and Recreation, State of Queensland Planning Principles and Implementation Notes for Local Government, Final Report September 2003http://www.nprsr.qld.gov.au downloaded in February 2014.

Sari Mutiara \& Kinoshita Isami, (2012), Characteristic of Public Small Park Usage in Asia Pacific Countries: Case Study in Jakarta and Yokohama City, Procedia - Social and Behavioral Sciences, 35, 412 - 419

Willemse, L. (2010). Community/ neighbourhood park use in Cape Town: A class-differentiated analysis. MA Thesis, University of Stellenbosch, Stellenbosch, South Africa as cited by H.E. Wright Wendel et al. (2012) , Accessibility and usability: Green space preferences, perceptions, and barriers in a rapidly urbanizing city in Latin America, Landscape and Urban Planning, 107, 272- 282 